\title{
Comparative Impact of Seasonal Variation on The Skin Depigmentation Activity, Antioxidant Capacities and Phytochemical Constituents of Aspilia Africana (Compositae) And Melanthera Scanden
}

\author{
Olugbenga Kayode Popoola ${ }^{1 *}$, Francis Jide Faleye ${ }^{2}$, Damilola Kayode Adekeye ${ }^{1}$, Taiwo Tolu- \\ wabori Ajayi ${ }^{1}$, Adeniyi Aremu Azimi ${ }^{2}$, Adeola Taoreed Ajao ${ }^{2}$ and Sunday Dele Oyeyemi ${ }^{3}$ \\ ${ }^{1}$ Department of Chemistry, Faculty of Science, Ekiti State University, Ado-Ekiti, Ekiti State, Nigeria
}

${ }^{2}$ Department of Industrial Chemistry, Faculty of Science, Ekiti State University, Ado-Ekiti, Ekiti State, Nigeria

${ }^{3}$ Department of Plant Science and Biotechnology, Faculty of Science, Ekiti State University, Ado-Ekiti, Ekiti State, Nigeria

Corresponding author: Olugbenga K Popoola, Department of Chemistry, Faculty of Science, Ekiti State University, Ado-Ekiti, Nigeria

\section{ARTICLE INFO}

Received: 幽 October 12, 2020

Published: October 23, 2020

Citation: Olugbenga Kayode P, Francis Jide F, Damilola Kayode A, Taiwo Toluwabori A, Adeniyi Aremu A, et al., Comparative Impact of Seasonal Variation on The Skin Depigmentation Activity, Antioxidant Capacities and Phytochemical Constituents of Aspilia Africana (Compositae) And Melanthera Scanden. Biomed J Sci \& Tech Res 31(3)-2020. BJSTR. MS.ID.005097.

Keywords: Aspilia Africana; Melanthera Scande; Antioxidant; Anti-Lipid Peroxidation; Cosmetics; Phytochemicals; Antityrosinase

\begin{abstract}
Medicinal plants are natural sources of affordable, safe and efficient oxidative stress and skin degenerative enzymes inhibitors. Thus, exploring their medicinal properties becomes a great importance and interests to researchers in the field of biomedicine. The present study investigates the comparative impacts of seasonal variation on the medicinal properties of aerial parts of Aspilia africana (Compositae) and Melanthera scanden with an insight of providing clues to further aid the ethnomedicinal applications and traditional uses of the plants. Samplings were carried out in both dry (January and October) and raining (April and July) seasons in Nigeria in the year 2018. Quantitative phytochemical determination of the plant materials includes the in-vitro battery of assays including: phenolics, flavonol and flavanol. Total antioxidant properties of the plants assayed include trolox equivalent antioxidant capacity (TEAC) and ferric reducing antioxidant potential (FRAP). Fe (II)-induced microsomal lipid peroxidation (LPO) assay as well as the tyrosinase inhibition activities of the plants was also evaluated in an in-vtro system. The results of this study showed that the phytochemicals were more concentrated in both plants during dry season than in raining season; both the antioxidant capacities, anti-lipid peroxidation and skin depigmentation inhibitory activities were higher for both plants in the dry than the wet season, The outcome of this study therefore becomes an added value to existing data on Aspilia africana (Compositae) and Melanthera scande. It also showed the best possible time for harvesting the plants for ethnomedicinal applications most especially in terms of their antioxidants and tyrosinase enzyme skin depigmentation activities which can possibly serve as raw materials for cosmetics product formulation.
\end{abstract}

\section{Introduction}

Medicinal plants are cheap sources of antioxidants with the ability to scavenge free radicals, thereby mitigating body exposure to cellular oxidative stress disorders [1]. Free radicals have gained importance in clinical medicine and biological science because of their logical consequences and health implications. Diverse chronic physiological disorders (e.g. skin hyperpigmentation) and degenerative heart related diseases such as early skin aging, coronary heart, inflammation, stroke, diabetes mellitus and cancer are often associated with the presence of free radicals and reactive oxygen species in the body systems [2,3]. The health implications and deleterious effects of free radicals as well as other oxidizing agents have been shown to rescind by plants containing phytochemicals such as flavanol, glycosides flavonoids, flavonol and phenolics [46]. The free radical scavenging capacity and antioxidant properties of medicinal plants depend largely on their phytochemical 
constituents while the potential use of plants with these properties for treating human ailments and oxidative stress related diseases have been reported in past and recent literatures [1], [7-9]. Some medicinal plants characterized with antioxidant properties have been shown to inhold enzymes inhibition properties. For instance, strong alpha amylase and alpha glucosidase inhibition activities of Triclisia subcordata Oliv was documented [1]. In another study, Hanh et al. showed the Inhibition activity of some Vietnamese folk plants which were aimed to be used in skin-whitening cosmetics [10]. A recent research showed that fermented South African Rooibos (Aspalathus linearis) has significant inhibitory effect on the enzyme tyrosinase present in the skin and they concluded that the plant may be essential in solving problems relating to skin hyperpigmentation [6]. Tyrosinase is a copper-containing enzyme which catalyzes the first two stages of melanin formation [11]. Over accumulation of melanin in the skin result in undesirable dark macromolecular pigment called skin hyperpigmentation [12]. The search for effective and efficient source of natural antioxidants, that can protect the human body from oxidative damage and retard the progress of many chronic oxidative stress related diseases with high safety margins, has therefore focused on the use of plant.

Plants like Aspilia africana (Compositae) and Melanthera scanden are one of medicinal plants considered of great biological importance. Aspilia africana (Compositae) is a semi- woody herb from a perennial woody root that grows up to 2 meters high and widely distributed across tropical Africa including Nigeria [13]. Melanthera scanden is a scandent or scrambling herb of waste thickets, commonly dispersed in the forested areas and extending widely across tropical Africa. The plant is often confused with Aspilia africana and has similar medicinal uses. It is known to provide forage for all stock in thicket edges around villages. On the other hand, both Aspilia africana (Compositae) and Melanthera scanden are fast-growing weeds of cultivation becoming troublesome in the southern Nigeria and in the western Cameroon where there are deemed a pest on oil-palm plantations. With haemostatic preparations they are used on cuts and wounds [14]. They are said to possess the ability to draw up exudations from open sores and promote healing as well as curbing inflammation $[15,16]$. Antidiabietic, antimicrobial, antioxidant, hypolipidemic, anti-inflammatory and antiplasmodial activities of the plants have been reported [14] [17-20]. The present study therefore focus on the comparative impact of seasonal variation on the medicinal properties (antityrosinase activity, antioxidant capacities and phytochemical constituents) of Aspilia africana (Compositae) and Melanthera scanden with an insight of providing clues to further aid the ethnomedicinal and ethnopharmacological applications of the plants.

\section{Materials and Methods}

\section{Materials}

Chemicals and Reagent: The Standards (purity > 99.0\%) used for antioxidant, anti-tyrosinase assays and inhibition of Fe (II) induced lipid peroxidation, such as gallic and kojic acids, as well as other reagents were secured from Sigma-Aldrich, Inc. (St. Louis, MO, USA).

\section{Methods}

Samples Collection And Preparation : The aerial parts (weighing $100 \mathrm{~g}$ each) of $M$. scandense and A. Africana were sourced from a natural habitat in Ureje area $\left(7.6175^{\circ} \mathrm{N}, 5.2573^{\circ} \mathrm{E}\right)$ of AdoEkiti, Ekiti State Nigeria between January and October, 2019. The plants were identified by the Herbarium Curator at the Department of Plant Science and Biotechnology, Ekiti State University, Ado-Ekiti, Nigeria, where a voucher specimen number UHAE2018/029 and UHAE2018/030 were respectively assigned to the $M$. scandense and A. Africana. The obtained plant materials were air dried at room temperature for three weeks, crushed separately using pestle and mortar. Thereafter, the samples were each pulverized by an electric blender into a homogenized powder, weighed and stored in different airtight sterile sample bottles pending analysis.

Extraction: The powdered materials were each extracted with methanol. Approximately $75 \mathrm{~g}$ each of the powdered materials was soaked in $1500 \mathrm{~mL}$ of the solvent in different vials for 72 hours. Each extract was filtered and concentrated at $45^{\circ} \mathrm{C}$ using rotary evaporator. The extracts were stored in different air tight sample vials pending analysis.

\section{Quantitative Analysis of Phytochemicals}

\section{A. Total Polyphenol}

The total polyphenolic content of the plants extract was determined using the Folin-Ciocalteu method as described with little modification [1]. Folin-Ciocalteu reagent and Distilled water were added to a $125 \mu \mathrm{L}$ of each solvent extract. Each mixture was allowed to stand for $10 \mathrm{~min}$ before the addition of sodium carbonate solution $(7.0 \% \mathrm{w} / \mathrm{v})$. The resultant mixture was allowed to stand for $120 \mathrm{~min}$; absorbance was thereafter read at $760 \mathrm{~nm}$ on a SpectrumLab70 Spectrophotometer. A gallic acid standard curve was obtained for the calculation of polyphenolic content and the result was expressed in terms of gallic acid in $\mathrm{mg} / \mathrm{mL}$ of extract. The experiment was carried out in triplicate.

\section{B. Determination of Flavanol}

The Flavanol content of each extract was determined in accordance to a previously described [21]. A $0.05 \%$ 
4-dimethylaminocinnamaldehyde (DMACA) solution $(25 \mathrm{~mL})$ was added to $50 \mathrm{mg}$ of each solvent extract. Each mixture was allowed to stand for $30 \mathrm{~min}$; absorbance was read at $640 \mathrm{~nm}$. The result was expressed in terms of catechin equivalents in $\mathrm{mg} \mathrm{CE} / \mathrm{g}$ of extract. The determination was carried out in triplicate.

\section{Determination of Flavonol}

The flavonol content of the samples was determined by adopting the method described [22]. $2 \mathrm{~mL}$ of $\mathrm{AlCl}_{3}$ prepared in ethanol and $3 \mathrm{~mL}$ of $50 \mathrm{~g} / \mathrm{L}$ sodium acetate solution were added to $2 \mathrm{~mL}$ of each extracted sample in test tubes and vortex mixed. The mixture was incubated for three hours $\left(3 \mathrm{hrs}\right.$.) at $20^{\circ} \mathrm{C}$; thereafter, series of stock solution of $20,40,60,80$, and $100 \mu \mathrm{g} / \mathrm{mL}$ were prepared. The absorbance was measured at $440 \mathrm{~nm}$ against blank at $593 \mathrm{~nm}$ using a SpectrumLab70 spectrophotometer. The total flavonol content was calculated in terms of quercetin equivalent in $\mathrm{mg} \mathrm{QE} / \mathrm{mL}$ of sample from the calibration curve. The experiment was carried out in triplicate.

\section{Total Antioxidant Capacities}

D. Trolox-Equivalent Antioxidant Capacity (TEAC)

Assay: The trolox-equivalent antioxidant capacity (TEAC) assay was carried out according to the spectrophotometric method described [23]. TEAC reagent was added to $25 \mathrm{mg}$ of each solvent extract. The mixture was incubated for $30 \mathrm{~min}$. The TEAC value was determined by measuring the absorbance at $734 \mathrm{~nm}$ on a plate spectrometer (Multiskan, Thermo Electron Corporation). The result was expressed in terms of trolox equivalents in $\mathrm{mM} \mathrm{TE} / \mathrm{g}$ of extract following an obtained calibration curve.

E. Ferric Reducing Antioxidants Potential (FRAP) Assay: The ferric reducing antioxidant power (FRAP) was performed according to the spectrophotometric methods described with little modification [24]. A $30 \mathrm{~mL}$ FRAP solution was added to $10 \mathrm{mg} / \mathrm{mL}$ of each extracted sample in test tubes and incubated at $37^{\circ} \mathrm{C}$ for 30 minutes alongside prepared blank samples. The absorbance of the samples was determined against blank at $593 \mathrm{~nm}$ on a plate spectrometer (Multiskan, Thermo Electron Corporation). A Series of stock solution: $20,40,60,80$, and $100 \mu \mathrm{g} / \mathrm{mL}$ was prepared and using aqueous solution of $\mathrm{FeSO}_{4} \cdot 7 \mathrm{H}_{2} \mathrm{O}$ as standard curve.

F. Fe (II)-Induced microsomal lipid peroxidation (LPO) assay: LPO was measured following the method described with some modifications [25]. The extracts and positive controls were prepared by incubating a mixture of $50 \mu \mathrm{L}$ anti-oxidative solutions corresponding to the extracts or the positive controls and 300 $\mu \mathrm{L}$ microsomes at $37^{\circ} \mathrm{C}$ for $30 \mathrm{~min}$ in a shaking water bath. 100 $\mu \mathrm{L}$ of $\mathrm{FeSO}_{4}$-solution and $\mathrm{KCl}$-buffer were thereafter added to the mixture. The mixtures were then incubated at $37^{\circ} \mathrm{C}$ for 1 hour in a shaking water bath. After the incubation, $1 \mathrm{~mL}$ TCA reagent was added to the tube containing each extract mixture, vortex mixed and centrifuged at $2000 \mathrm{rpm}$ for $15 \mathrm{~min}$. After centrifugation, the supernatants were decanted whereof $1 \mathrm{~mL}$ of each supernatant was removed and added to new test tubes containing $1 \mathrm{~mL} 0.67 \%$ TBA solution. The samples were further vortexed and heated for 20 min at $90^{\circ} \mathrm{C}$ in a water-bath. Absorbance of the samples and control was measured at $532 \mathrm{~nm}$. The percentage inhibition was measured according to Equation (I), while the reported and IC $_{50}$ value was calculated from the plot of percentage anti-lipid peroxidation activities against concentration in

$$
\% \text { inhibition }=\frac{\text { Acontrol }- \text { Asample }}{\text { Acontrol }} \times 100 \text {. }
$$

Tyrosinase Enzyme Assay: A previous method described was adopted with slight modification [26]. Each extract was assayed for tyrosinase inhibition by measuring its effect on tyrosinase activity in a 96-well reader. The reaction was carried out at room temperature. The reaction mixture of $30 \mu \mathrm{L}$ potassium phosphate buffer (50 Mm, pH 6.8) and 343 units/mL mushroom tyrosinase and $110 \mu \mathrm{L}$. L-tyrosine $2 \mathrm{mM}$ was pre-incubated for 15 mins before adding L-tyrosine. Then the mixture was further incubated for 15 mins before measuring the absorbance at $490 \mathrm{~nm}$. The reaction mixture without L-tyrosine was used as blank while the reaction mixture with the corresponding solvents (without plant material) was used as control. Kojic acid was served as the positive control. The percentage inhibition of tyrosinase was calculated according to Equation (II) and IC50 value $(\mu \mathrm{g} / \mathrm{mL})$ was calculated from the plot of percentage inhibition of tyrosinase against concentration.

$$
\text { Tyro } \sin \text { aseinhibition }(\%)=\frac{(A-B)-(C-D)}{(A-B)} \mathrm{X} 100 \ldots \ldots \ldots \ldots \ldots . . .(I I)
$$

$A=$ Absorbance of control with enzyme;

$\mathrm{B}=\mathrm{Absorb}$ ance of the control without enzyme;

$\mathrm{C}=$ Absorbance of sample with enzyme;

$\mathrm{D}=$ Absorbance of sample without enzyme.

\section{Statistical Analysis}

The data presented in all the experiments are means \pm SD obtained for all in vitro experiments in triplicate. FRAP, phenolics, TEAC, flavanol, flavonoids and flavonol values were determined using their respective templates, while the results of tyrosinase enzyme inhibitory and Fe (II)-induced lipid peroxidation assays were expressed as percentage inhibitions \pm SD.

\section{Results and Discussion}

Table 1 of this report contained the quantitative constituents of the phytochemical compounds of the various M. scandens and A. Africana collected at different seasons. It is well known that plants contained active phytochemicals that are responsible for their medicinal properties [7-9] [27,28]. The amount and type of bioactive compounds present in plants are dictated by factors which include: chemical profile of the soil, nature of the plant, 
and environment in which the plants grow as well as seasonal variation of the plant's environment. The present study investigates quantitatively the presence of flavanol, flavonol and phenolics in the aerial parts of Aspilia africana (Compositae) and Melanthera scanden as well as the impact of seasonal variation on their relative abundance in the plants. The phenolic content of the Melanthera scanden ranged between $179.73 \pm 0.20 \mathrm{mg} \mathrm{GAE} / \mathrm{mL}$ in the month of July to $222.04 \pm 1.58 \mathrm{mg} \mathrm{GAE} / \mathrm{mL}$ in October while that of Aspilia Africana ranged between $119.20 \pm 0.09$ and $137.93 \pm 0.14 \mathrm{mg} \mathrm{GAE} /$
$\mathrm{mL}$ in same months as shown in Table 1. The phenolic content of both plants was highest in October and lowest in July with variation observed for all the months. Flavanol (35.79 $\pm 2.90 \mathrm{mg} \mathrm{CE} / \mathrm{g})$ and flavonol (20.56 $\pm 2.98 \mathrm{mg} \mathrm{QE} / \mathrm{mL})$ showed higher concentration in the dry period (October) that the wet periods. This implies that the phytochemicals were more concentrated in the plants during dry season than raining season, while differences in results of each sampling period showed that concentration of the phytochemical varies and changes with season.

Table 1: Phytochemical Constituents of M. scandens and A. Africana found in Nigeria.

\begin{tabular}{|c|c|c|c|c|}
\hline \multirow{2}{*}{ Plant } & Season & Phenolic (mg GAE/mL) & Flavanol (mg CE/g) & Flavonol (mg QE/mL) \\
\hline \multirow{4}{*}{ Melanthera scandens } & January & $215.84 \pm 0.54$ & $30.69 \pm 2.54$ & $19.12 \pm 0.81$ \\
\cline { 2 - 5 } & April & $185.98 \pm 0.53$ & $27.73 \pm 0.65$ & $17.61 \pm 7.41$ \\
\cline { 2 - 5 } & July & $179.73 \pm 0.20$ & $26.39 \pm 2.91$ & $17.29 \pm 3.98$ \\
\cline { 2 - 5 } & October & $222.04 \pm 1.58$ & $35.79 \pm 2.90$ & $20.56 \pm 2.98$ \\
\hline \multirow{3}{*}{ Aspilia africana } & January & $123.14 \pm 0.79$ & $51.58 \pm 2.42$ & $34.16 \pm 2.98$ \\
\cline { 2 - 5 } & April & $120.94 \pm 0.78$ & $41.88 \pm 1.56$ & $31.29 \pm 0.24$ \\
\cline { 2 - 5 } & July & $119.20 \pm 0.09$ & $34.82 \pm 4.43$ & $35.88 \pm 3.93$ \\
\cline { 2 - 5 } & October & $137.93 \pm 0.14$ & $55.59 \pm 1.57$ & 0.19 \\
\hline
\end{tabular}

In Table 2, we reported the total antioxidant capacities of the methanolic extracts of M. scandens and A. Africana collected between January and October, 2018 in Nigeria. The presence and abundance of the evaluated phytochemicals in Aspilia africana (Compositae) and Melanthera scanden showed that the plant materials may be used as natural antioxidants that could exert protective effects against diseases like cancer, liver diseases, cardiovascular disease and disorders skin hyperpigmentation. Free radical scavenging activities of the plants were further investigated to ascertain their antioxidant properties in support of previously reported literatures and to know how these properties change with season. The results of this study (Table 2) showed good antioxidant activities of the plant materials. The FRAP value of the Melanthera scanden was highest in October ( $458.49 \pm 0.59 \mathrm{mg} / 100 \mathrm{~mL}$ ) and lowest in July (321.28 $\pm 9.88 \mathrm{mg} / 100 \mathrm{~mL})$. Similarly for Aspilia Africana, FRAP was found maximum in October and minimum in July with the values of $151.72 \pm 1.25$ and $110.79 \pm 3.82 \mathrm{mg} / 100 \mathrm{~mL}$ respectively; relative values were also recorded for January and April respectively. Evaluation of the TEAC of both plant materials showed similar trend in activity variation with season; while October possess the highest values, July had the lowest values (Table 2). These results may be justified by concentration values of the evaluated phytochemicals; such that the higher the concentration of the phytochemicals in the plant, the higher the antioxidant capacities of the plants tend to be and vice versa. This trend was also observed in the works reported [1]. Overall, the results this study thus confirm the potency of the plant materials to scavenge free radicals, while the properties also vary with season.
Table 2: Total Antioxidant Capacities M. scandens and A. Africana.

\begin{tabular}{|c|c|c|c|}
\hline Plant & Season & TEAC $(\boldsymbol{\mu M}$ TE/g) & FRAP $(\mathbf{m g} / \mathbf{1 0 0} \mathbf{~ m L})$ \\
\hline \multirow{4}{*}{$\begin{array}{c}\text { Melanthera } \\
\text { scandens }\end{array}$} & January & $405.22 \pm 3.27$ & $455.28 \pm 2.04$ \\
\cline { 2 - 4 } & April & $311.84 \pm 7.82$ & $431.49 \pm 13.32$ \\
\cline { 2 - 4 } & July & $237.31 \pm 3.34$ & $321.28 \pm 9.88$ \\
\cline { 2 - 4 } & October & $620.99 \pm 5.45$ & $458.49 \pm 0.59$ \\
\hline \multirow{4}{*}{$\begin{array}{c}\text { Aspilia afri- } \\
\text { cana }\end{array}$} & January & $722.86 \pm 2.69$ & $120.01 \pm 0.69$ \\
\cline { 2 - 4 } & April & $711.11 \pm 0.71$ & $124.43 \pm 1.18$ \\
\cline { 2 - 4 } & July & $699.90 \pm 1.42$ & $110.79 \pm 3.82$ \\
\cline { 2 - 4 } & October & $779.94 \pm 3.38$ & $151.72 \pm 1.25$ \\
\hline
\end{tabular}

In Table 3, we have the half maxima inhibitory activities of both M. scandens and A. Africana on the factor of Iron-II induced anti-lipid peroxidation and skin pigments formation under various seasons. Further, the plant materials were investigated for their iron (II)-induced lipid peroxidation inhibitory activities. The results of this study showed variations in the activities of the plant materials to inhibit peroxidation of lipids with seasons. Here, both plants of interest showed better performance when harvested in the dry than the raining season. The optimum performance efficiency and inhibition activities reached the values of 123.00 and $86.25 \mu \mathrm{g} /$ $\mathrm{mL}$ in January for the Melanthera scanden and Aspilia africana (Compositae) respectively (Table 3). When harvested in July, both plants showed weakest LPO inhibition potentials. All months and seasons possess varying degree of impacts on the anti-lipid peroxidation activities of the plants materials. In like manner, skin depigmentation activities were observed for both plants. The plant materials were able to inhibit tryosinase, the enzyme responsible 
for skin pigmentation. The antityrosinase activities of the plant materials were found to be higher in the dry season (January) than in the other sampling periods with the respective values of $53.00 \mu \mathrm{g} / \mathrm{mL}$ and $54.75 \mu \mathrm{g} / \mathrm{mL}$ for $M$. scandens and A. Africana respectively. Inhibition activity values of 144.88 and $137.00 \mu \mathrm{g} / \mathrm{mL}$ were recorded respectively for the Melanthera scanden respectively and Aspilia africana (Compositae) in July; while the values of 54.75 and $86.25 \mu \mathrm{g} / \mathrm{mL}$ were each recorded in January for the Melanthera scanden and Aspilia africana (Compositae) as shown in Table 3. The Melanthera scanden plant material showed better though mild inhibition activity of the LPO and LYR when compared with their counterpart gallic acid and acid kojic acid used as control in these experiments. Overall, this study showed that the plant materials possess both anti-lipid peroxidation activities and tyrosinase inhibition activities which are dependent on the time of harvest. Thus, the presence of different biologically active compounds in the plant materials is accountable for their LPO and enzyme inhibition activities. In line with this study are previous works reported [27, $29,30]$.

Table 3: $I C_{50}$ of Fe-II induced Lipid Peroxidation and Skin Pigmentation Inhibitory Activities.

\begin{tabular}{|c|c|c|c|}
\hline Plant & Season & LPO $(\boldsymbol{\mu g} / \mathbf{m L})$ & TYR $(\boldsymbol{\mu g} / \mathbf{m L})$ \\
\hline \multirow{4}{*}{$\begin{array}{c}\text { Melanthera } \\
\text { scandens }\end{array}$} & January & 123.00 & 53.00 \\
\cline { 2 - 4 } & April & 149.25 & 81.88 \\
\cline { 2 - 4 } & July & 150.01 & 144.88 \\
\cline { 2 - 4 } & October & 151.00 & 89.750 \\
\hline \multirow{4}{*}{ Aspilia africana } & January & 86.25 & 54.750 \\
\cline { 2 - 4 } & April & 114.25 & 68.750 \\
\cline { 2 - 4 } & July & 133.50 & 137.00 \\
\cline { 2 - 4 } & October & 107.25 & 77.50 \\
\hline Gallic acid & - & 19.50 & NA \\
\hline Kojic acid & - & $\mathrm{NA}$ & 12.25 \\
\hline
\end{tabular}

\section{Conclusion}

In support of previous studies, the present study has confirmed the presence of phenolics, flavanol and flavonol in the evaluated Aspilia africana (Compositae) and Melanthera scanden. These bioactive phytochemicals are responsible for the antioxidant activities, anti-lipid peroxidation, and tyrosinase inhibition activity of the plant materials. The outcome of this research further showed that the concentrations of the phytochemicals varied with season. The phytochemical are more abundant in the dry season than in the wet season. The antioxidant activities of both plant materials were concentration dependent and correlation was observed between the antioxidant activities of the plant materials and the concentration of their evaluated phytochemicals. The plant materials also demonstrated mild anti-lipid peroxidation and inhibition activities against the formation of pigments on the surface of the skin when compared to those of the controls.
The outcome of this study becomes an added value to existing data on Aspilia africana (Compositae) and Melanthera scande as it showed the best possible time for harvesting of the plants for ethnomedicinal applications most especially in terms of their antioxidants and enzyme inhibition activities. The novelty of this study confirms the application of the plants for problem solving involving hyperpigmentation.

\section{References}

1. Akinwunmi OA, Adekeye DK, Olagboye SA (2020) Phytochemical quantification, in vitro antioxidant and antidiabetic potentials of methanol and dichloromethane extracts of Triclisia subcordata (Oliv) leaves. Trends in Phytochemical Research 4(1): 17-24.

2. Zhou Z-Q, Xiao J, Fan H-X, Yu Y, He RR, et al. (2017) Polyphenols from Wolfberry and their bioactivities. Food Chemistry 214: 644-654.

3. Farzaei H, Rahimi MR, Abdollahi M (2015) The role of dietary polyphenols in the management of inflammatory bowel disease. Current Pharmaceutical and Biotechnology 16(3): 196-210. PMID: 25601607.

4. Dasgupta N, De B (2007) Antioxidant activity of some leafy vegetables of India: A comparative study. Food Chemistry 101(2): 471-474.

5. Rabeta MS, Nur FR (2013) Total phenolic content and ferric reducing antioxidant power of the leaves and fruits of Garcinia atrovirdis and Cynometra cauliflora. International Food Research Journal 20(4): 16911696.

6. Popoola OK (2019) Skin depigmentation profiles of ethanolic fraction of the South African "Green" Cyclopia intermedia and other related biological potentials. American Journal of Biological Chemistry 7(5): 6571.

7. Shetti A, Sanakal R, Kaliwal B (2012) Antidiabetic effect of ethanolic leaf extract of Phyllanthus amarus in alloxan induced diabetic mice. Asian Journal of Plant Science Research 2(1): 11-15.

8. Ahmed M, Khan MI, Khan MR, Muhammad N, Khan AU, Khan AR (2013) "Role of medicinal plants in oxidative stress and cancer", OMICS Publishing Group 2: 641.

9. Wesam K, Maryam F, Zahra A, Damoon A, Majid A (2016) The role of medicinal plants in the treatment of diabetes: A systematic review. Journal of Electronic Physician 8(1): 1832-1842.

10. Hanh NTM, Phung NKP, Phuong QND (2017) Studying on tyrosinase inhibition activity of some Vietnamese folk plants aims to use in skinwhitening cosmetics. American Journal of Plant Sciences 8: 1319-1328.

11. Te-Sheng C (2009) An update review of tyrosinase inhibitors. International Journal of Molecular Sciences 10(6): 2440-2475.

12. Moon J, Yim E, Song G, Lee NN, Hyun C (2010) Screening of elastase and tyrosinase inhibitory activity from Jeju Island plants. EurAsian Journal of Biosciences 4: 41-53.

13. Dalziel JM (1973) The useful plants of West African. Crown Agents. London.

14. Okoli CO, Akah PA, Okoli AS (2007) Potentials of leaves of Aspilia africana (Compositae) in wound care: An experimental evaluation. BMC Complementary and Alternative Medicine 7(24): 171-194.

15. Dimo T, Tan PV, Dongo E, Kaintchouing P, Raktoniria SV (2002) In Vitro vascular smooth muscle contractile activity of Aspilia Africana extract on rat aortic preparation. Pharmazie 57(6): 421-423.

16. Agyare $C$, Asase A, Lechtenberg M, Niehues M, Deters A, et al. (2009) An ethnopharmacological survey and in vitro confirmation of ethnopharmacological use of medicinal plants used for wound healing in Gosomtwi-Atwima-Kwanwoma area, Ghana. Journal of Ethnopharmacology 125(3): 393-403. 
17. Adeniyi BA, Odufowora RO (2000) In-vitro anti-microbial properties of Aspilia africana. African Journal of Biomedical Research 3(3): 167-170.

18. Guede ZN, Mambu L, Guede-Guina F, Bodo B, Grellier P, et al. (2005) In vitro antiplasmodial activity and cytotoxicity of 33 West African plants used for treatment of malaria. Journal of Ethnopharmacology 98(3): 281-285.

19. Adeseguna SA, Alabia SA, Olabanja PA, Alexander H, Coker B (2010) Evaluation of antioxidant potential of Melanthera scandens. Journal of Acupuncture and Meridian Study 3(4): 267-271.

20. Offong E (2011) Antidiabetic and hypolipidemic activities of Melanthera scadens (M.Sc. dissertation). University of Uyo, Uyo, Nigeria.

21. Treutter D (1989) Chemical reaction detection of catechins and proanthocyanidins with 4-dimethylaminocinnamaldehyde. Journal of Chromatography A 467: 185-193.

22. Neo YP, Ariffin A, Tan CP, Tan YA (2008) Determination of oil palm fruit phenolic compounds and their antioxidant activities using spectrophotometric methods. International Journal of Food Science and Technology 43(10): 1832-1837.

23. Pellegrini N, Serafini M, Colombi B, Del Rio D, Salvatore S, et al. (2003) Total antioxidant capacity of plant foods, beverages and oils consumed in Italy assessed by three different in vitro assays. Journal of Nutrition 133(9): 2812-2819.

24. Benzie IFF, Strain JJ (1996) The ferric reducing ability of plasma (FRAP) as a measure of "antioxidant power": the FRAP assay. Analytical Biochemistry 239(1): 70-76.

\section{ISSN: 2574-1241}

DOI: 10.26717/BJSTR.2020.31.005097

Olugbenga Kayode Popoola. Biomed J Sci \& Tech Res

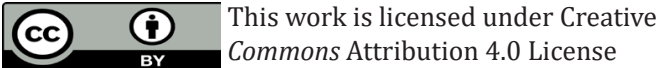

Submission Link: https://biomedres.us/submit-manuscript.php
25. Snijman PW, Joubert E, Ferreira D, Li XC, Ding Y Green IR, et al. (2009) Antioxidant activity of the dihydrochalcones Aspalathin and Nothofagin and their corresponding flavones in relation to other Rooibos (Aspalathus linearis) Flavonoids, Epigallocatechin gallate, and trolox. Journal of Agriculture and Food Chemistry 57(15): 6678-6684.

26. Chompo JA, Upadhyay M, Fukuta S, Tawata S (2012) Effect of Alpinia zerumbet components on antioxidant and skin disease-related enzymes. BMC Complementary and Alternative Medicine 12(1): 106-114.

27. Popoola OK, Adedara TO, Ajao AT, Akinrinlola M, Olasanmi AO (2019) Effect of Fermentation on the Factor of Skin bPigmentation Inhibitory Activity and Total Antioxidant Capacities Demonstrated by the South African Rooibos (Aspalathus linearis). Biomedical Journal of Scientific \& Technical Research 20(4): 15195- 15202.

28. Ohunayo A, Adekeye D, Dauda O, Odeniyi I, Popoola O, et al. (2020) Microbial profile of the Phyllosphere and the antimicrobial potency of Ficus vogelii extracts. Journal of Pharmaceutical Sciences and Research 12(1): 191-195.

29. Singleton O, Rosa M, Vernon l (1999) Analysis of total phenols and other oxidation substrates and antioxidants by means of folin-ciocalteu reagent. Method of Enzymology 299: 157-178.

30. Karamian R, GhasemLou F (2013) Screening of total phenol and flavonoid content, antioxidant and antibacterial activities of the methanolic extracts of three Silene species from Iran. International Journal of Agriculture and Crop Science 5: 305-316.

$\begin{array}{ll}\text { BIOMEDICAL } & \text { Assets of Publishing with us } \\ \text { RESEARCHES } & \text { - Global archiving of articles } \\ & \text { - Immediate, unrestricted online access } \\ & \text { - Rigorous Peer Review Process } \\ & \text { - Authors Retain Copyrights } \\ \end{array}$

